there is evidence of extensive desiccation in western North America, southern South America, north-central Africa, and central Australia; and physical changes which are not yet understood led to a glacial epoch in the northern hemisphere in Pleistocene times. These phenomena had doubtless much to do with the extinction of the large quadrupeds and the impoverishment of the mammal fauna. Civilised man has continued the destruction.

The whole of this fascinating story is told in detail by Prof. Osborn, who not only discusses the mammals themselves, but also describes the rocks in which their remains occur, and briefly notices the successive changes in geography which they indicate. His work is illustrated by numerous text-figures of skeletons, restored sketches of extinct mammals made by the American Museum of Natural History, photographs of scenery, and diagrammatic geological sections. As might be supposed, much of it is extremely technical, and to be used for reference rather than systematic reading; but it is enlivened throughout by a succession of interesting generalisations, which are all the more valuable as having been either suggested or confirmed by the author's own researches. The peculiar feature of Prof. Osborn's book, indeed, is its stimulating freshness, and he is to be congratulated on the impulse which it is certain to give to the studies with which it deals.

A. S, W.

\section{GEOGRAPHICAL DISTRIBUTION OF FERNS.}

Die Geographie der Farne. By H. Christ (Basel)

Pp. $357+3$ maps. (Jena: Gustav Fischer, IgIo.) Price 12 marks.

$\mathrm{D}^{\mathrm{R}}$ CHRIST has produced a volume of remarkable interest on the geographical distribution of ferns, which forms a worthy companion to Schimper's well-known "Pflanzen-Geographie auf physiologischen Grundlage." The book has been arranged in a somewhat similar manner to Schimper's "Plant Geography," and is divided into two parts. The first consists of ${ }^{2} 3^{6}$ pages, devoted to considerations of the effects of soil, climate, \&c., on the distribution of ferns, and in the second part the ferns of the different geographical areas are described in detail.

To the general botanist, and more particularly to the ecologist, the first portion of the book has the greater interest. Ferns, unlike the flowering plants, though very widely distributed, are not universally found over the surface of the earth, since they are definitely limited as to their environment by the need for water, and though many species are remarkable for their capability of resisting desiccation, yet they are unable to grow where the rainfall is below a certain amount. Being in the main shade plants, their maximum distribution tends to follow the wooded areas of the globe; and the dry desert areas are almost destitute of ferns.

Though mainly found growing on humus, some ferns are affected by the nature of the substratum, and this is especially the case with calcareous soils. It may often happen, however, that chalk-shunning ferns may be found on that formation owing to the NO. 2 I96, VOL. 88$]$ depth of humus by which the calcareous soil is overlaid.

Striking examples of ferns which avoid the chalk are afforded by Asplenium septentrionale and by the world-wide Pteridium aquilinum-the bracken fernwhich is found in both hemispheres, from "the equator to the poles." Asplenium viride and Cystopteris montana, on the other hand, may be cited as examples of species characteristic of the chalk. Halophytes, again, have their fern representatives, and Acrostichum lomarioides from the brackish swamps of tropical America, and A. aureum, which grows in the Rhizophora estuaries, are striking examples of this type of plant.

Then again there are the fresh-water swamp ferns, such as the widely distributed Dryopteris thelypteris and the well-known water fern, Ceratopteris thalictrioides.

The majority of ferns are perennial, but there are a few exceptions, of which Ceratopteris is one, and also the annual fern, Anogramma leptophylla.

Ferns afford parallels to Phanerogams in their choice of habitats and relations to clinatic conditions, and also in their external forms they provide counterparts to other types of vegetation. We find them, for example, as epiphytes; tree ferns; seramblers or bramble ferns (Gleichenia, Odontosoria, \&c.); twining ferns, such as Blechnum volubile; tendril climbers (Lathyropteris madagascariensis), and creeping epiphytes or rhizome climbers, which are well illustrated by the aroid-like Oleandra neeriformis.

The general biological features of hygrophytic ferns, hairs, secretions, storage organs, \&c., are also described with a wealth of illustration.

An interesting section is devoted to the description of the xerophytic types, many of which have their home in the Andes, on the same lines as that for the hygrophytes. Two characteristic forms may be recognised: the Cheilanthes type, with short rhizome, deep roots, and small hairy pinnæ, and the Elaphoglossum type, where the rhizome is thick and creeping and the leaves tongue-like, leathery, and simple. The genera Cyclophorus, from the Old World, and Elaphoglossum, centred in the Andes, afford the most striking examples.

Ferns of high alpine or arctic regions are few, and, as compared with the phanerogamic vegetation of such situations, are not particularly characteristic. Cryptogramma and Woodsia, however, may be cited as typically northern alpine forms, while Polystichum mohrioides is a typical antarctic-andine species. One of the highest known species is another Polystichum, $P$. Duthei, from Kumaon, which occurs at an altitude of from 13,000 to 17,000 feet.

The bulk of the second part of the book is concerned with the fern flora of the different geographical re. gions, but it is preceded by some very interesting pages dealing with general questions of geographical distribution, such as the effect of the Ice age and the relics of the fern flora of past ages. The distribution of several genera is outlined, but space does not permit of a review of this section of the book in further detail. Attention may, however, be directed to the remarkable case of distribution afforded by 
the genus Pleurosorus, which is found as three scarcely differing forms in Southern Spain (P. Pozoi), South Chile (S. papaverifolius), and Australia (P. rutaefolius). These small xerophytic rock ferns may well be cited as examples of the simultaneous appearance of a species in widely separated localities.

There is but one fault to find with this otherwise excellent book, and that is that the illustrations, most of which are very good, have been inserted without any particular reference to the text, and some difficulty is experienced in attempting to find the figures which are intended to illustrate particular descriptions.

A. W. H.

\section{OPHTHALMIC THERAPEUTICS.}

An International System of Ophthalmic Practice. Edited by Dr. Walter L. Pyle. Therapeutics. By Dr. A. Darier. Translated by S. Stephenson. Pp. xiv + 444. (London: Rebman, Ltd., I9II.) Price I7s. $6 d$. net.

THIS is the first volume of an "International System of Ophthalmic Practice," edited by Dr. Walter L. Pyle, of Philadelphia. Other volumes announced are on "Medical Ophthalmology," by Dr. Arnold Knapp, of New York; "Ophthalmic Diagnosis," by. Dr. Charles H. Beard, of Chicago; "Pathology and Bacteriology of the Eye," by Messrs. Treacher Collins and M. S. Mayou, of London; "Affections of the Orbit and Accessory Cavities," by Dr. Christian R. Holmes, of Cincinnati; "Examination and Refraction of the Eye and Eye-strain," by the editor; and "Ophthalmic Surgery," the authorship of which is not stated. It will be seen that the scheme is comprehensive, and that the aim is essen. tially practical. The authors are men of established reputation, and may be relied upon to carry out their work ably, so that the system will form a valuable, if not indispensable, addition to the ophthalmologist's library. If the volumes reach the standard of the sample which we have before us we may confidently prophesy the financial success of the series.

Those who have read Dr. Darier's lectures and papers on ophthalmic therapeutics in their original form in French must have approached the present work with some misgivings. Dr. Darier is an enthusiast for novae res. He possesses in marked degree the mental agility of the Latin race, quick to appreciate new facts, eager to traverse new paths. True, he sometimes appears to the onlookers to skip rather than to run, but then he is an artist, and a savour of art is not without its uses in dealing with the science of medicine, a science which, though yet in its infancy, is called upon to perform the feats of mature development. Dr. Darier's enthusiasm often outruns discretion, but in this book it has been curbed by the "free editorial control" which has been exercised upon the manuscript. In the end we have a sound work on the treatment of diseases of the eye, which by virtue of the large space devoted to the discussion of new methods and new drugs, forms a useful adjunct to the formal text-book.

The subject is divided into two parts, general and special therapeutics. The first commences with a NO. 2 I96; VOL. 88 ] chapter on methods of diagnosis, devoted to such topics as serum diagnosis and the demonstration of spirochætes. Constitutional treatment is then dealt with, stress being laid upon the technique of hypodermic and intravenous medication and subconjunctival injections. The chapter on serum- and organotherapy will prove particularly useful to the ophthalmologist, who has perforce to obtain his knowledge of these matters second-hand. It might have been expanded with advantage, and a freer citation of original papers would have enhanced its value. The ophthalmologist cannot afford to ignore serumtherapy, which now has so large a place in medical treatment, but it is a two-edged weapon, and should be used with the utmost caution. Much space is devoted to photo-electro-, hydro-, mechano-the:apy, $\mathrm{X}$-rays, and radium; as a rule original papers are quoted, and the reader is left to draw his own conclusions. Of more value are the chapters on drugsanæsthetics, analgesics, vaso-dilators, vaso-constrictors, mydriatics and cycloplegics, miotics and silver compounds; their virtues and vices and the modes of their application are quite well described.

In the section on special therapeutics, the diseases of the eye are dealt with seriatim in the manner of an ordinary text-book. Too little stress is laid upon old and well-tried methods, so that the reader is liable to obtain a wrong perspective. The book, however, is clearly intended for specialists who are capable of forming an independent opinion in these matters. It would be easy to criticise many of the statements, but those most open to attack are such as only time and extended experience can ultimately settle. They are topics of constant dispute in ophthalmic journals, where they can most suitably be ventilated. In discussing cataract, glaucoma, and so on reference has to be made to operative measures. It would have been better to have relegated these matters entirely to the volume on ophthalmic surgery, where they will doubtless be treated exhaustively. The cursory remarks are of little value; on the other hand, they do not occupy much space.

We can cordially recommend the book to the consideration of advanced students of ophthalmology, and they will be well advised to look out for the other volumes of the series.

PHARMACOGNOSY IN THE UNITED STATES. A Text-book of Botany and Pharmacognosy, intended for the Use of Students of Pharmacy, as a Reference Book for Pharmacists, and as a Handbook for Food and Drug Analysts. By Prof. H. Kraemer. Fourth revised and enlarged edition. Pp. viii +888 . (Philadelphia and London: J. B. Lippincott Co., n.d.) Price I5s. net.

$\triangle$ LTHOUGH in English text-books botany is not A usually combined with pharmacognosy, it is undeniable that such a combination possesses for the student of the latter science the distinct advantage that much overlapping may be avoided, and that, by selecting medicinal plants to illustrate the botanical portion, the student, while studying botany, insensibly acquires a considerable amount of information con. 